\title{
The Application of Model of Input and Output Transformations in Measuring Business Performance
}

\author{
Martina Mokrišová ${ }^{1, *} \&$ Jarmila Horváthová ${ }^{1}$ \\ ${ }^{1}$ Faculty of Management, University of Prešov, Konštantínova 16, 08001 Prešov, Slovakia \\ *Correspondence: Faculty of Management, University of Prešov, Konštantínova 16, 08001 \\ Prešov, Slovakia. E-mail: martina.mokrisova@unipo.sk
}

Received: January 10, 2018 Accepted: February 12, 2018 Published: February 24, 2018

doi: 10.5296/rae.v10i1.12738 URL: https://doi.org/10.5296/rae.v10i1.12738

\begin{abstract}
Performance is a term which we use in everyday life. One of the areas of its application is business performance, which is the subject of our research. Business performance depends on a number of factors. There are also several methods in theory how to measure business performance. The aim of this paper was to point out the possibility of the application of matrix model as one of the modern methods of performance measurement. This method provides opportunities for various calculations and economic analysis. In this paper we applied one of them - the model of input and output transformations applying simplex method of linear programming. We used the model of input and output transformations for the calculation of business efficiency. Our goal was to use this model for the calculation of business performance and to highlight the fact that efficiency and performance are related, or even they have the same meaning. We applied Spearman`s rank correlation coefficient to confirm the match of rankings of business performance and efficiency. We found out that there is relationship between performance and efficiency. With the use of mentioned approach we can calculate performance of individual businesses or industry and we can also formulate solutions for performance enhancement.
\end{abstract}

Keywords: Business, Efficiency, Matrix, Model, Performance 


\section{Introduction}

The current business environment puts efficiency and performance into the attention of every business interested in developing and increasing its competitiveness. Business performance indicators provide more dynamic and perspective picture of competitive position of a business and the potential for further improvement of its performance. The paper focuses on concepts used to measure and evaluate business performance and efficiency, which are currently very actual issue. What exactly means the magic word 'performance'? Why and for whom we measure business performance and its efficiency? We will try to answer these questions in this paper.

\section{Literature review}

Firstly it is necessary to focus on the definition of performance. Performance is a term which we use quite frequently in everyday life, regardless of our professional or interest focus. As the term performance is used in various fields, from sport to the world economy, we can find many answers to the question of what performance means.

In general, business performance is defined as "the operational ability to satisfy the desires of the company's major shareholders" (Smith, Reece 1999, p. 153), and it must be assessed to measure an organisation's accomplishment.

According to Wagner (2009) performance generally means a characteristic that describes the way in which an enterprise carries out a certain activity similar to the way in which this activity is performed. The interpretation of performance assumes the ability to compare the examined and reference way of performing activities according to the selected criterion range.

According to Fibírová and Šoljaková (2005) the term performance is used to define the essence of the existence of an enterprise in market environment, its success and ability to survive in the future. Sedláček, Suchánek and Špalek (2012) add that this term is associated with the realized output of the business and performance can be relatively easy quantified and then further analysed.

There are many different definitions of business performance. Souček (2010) characterizes business performance as the ability of a business to produce a summary of goods and services over a certain period of time and a company that wants to win must have at least twice the value of performance than the industry average. Suchánek (2013) approaches to performance similarly; according to him business performance can be understood in relation to business production capacity, resp. the performance that an enterprise achieves as an output from the production process. Another definition describes business performance as company`s ability to transform inputs to outputs (Johnson, Kevan 2000).

Among the representatives who understand the performance as the company`s ability to capitalize its investments embedded into business in the best way are the authors Neumaierová, Neumaier (2002); Frost (2005); Šulák, Vacík (2005). Specific issue is the 
different performance evaluation of various business entities such as owners, managers and customers (Šulák, Vacík 2005). Business performance can be evaluated differently. It depends on market participant who makes the review (Stýblo 2008). Valach (1998) approaches to the definition of performance in the same way - he points out that important is the participant for whom the evaluation is done, whether it's a customer or shareholder. The performance of an enterprise is high when it satisfies customer product requirements. From the perspective of the owner, the performance of a business is high when it provides adequate return related to risk.

Neumaierová (2003) states that the value of the company is determined by its performance. In order to increase the value of a business, it is necessary to increase its performance. According to this theory, business is a tool whose task is capitalization of shareholder investments. Several authors indicate the need for the comparison of performance with the target value (Nenadál 2004).

Performance has to be examined from several points of view. In the United Kingdom, the „Three E“ model has been used since the early 1980s. These are Economy, Efficiency and Effectiveness. Some authors identify the terms performance and efficiency. For this reason it can be stated that efficiency is an important precondition for business performance, respectively business performance can be measured by efficiency as it represents one aggregate value composed of business financial health and performance assessment. Doyle (1998) differentiates the efficiency as performance, which is determined by relationship between outputs and inputs, is easily measurable and in most cases can be easily improved; and the efficiency as effectiveness which talks about the ability to meet customer needs, is given outwards, is hardly measurable and its achievement is usually a longer process. According to Sink and Tuttle model from 1989, the performance is given by equation which members are the following performance criteria: effectiveness, efficiency, quality, productivity and quality of working life, innovation and profitability. Firstly it is important to put emphasize on effectiveness, it means that we have to do the right things. After the fulfilment of this most fundamental objective, we focus on efficiency and quality. If we can meet these criteria, our organization will be productive. Innovation and quality of working life act in the equation as regulators, which reduce, respectively increase performance. Meeting all these criteria guarantee not only the survival but also the profitability and growth of the organization (Rolstadas 2014).

In current economic practice, the definition of efficiency has not been unified yet. This issue is addressed by a number of authors whose opinions are in some cases the same and in other cases they complement. The diversity of the term efficiency can be seen in the following formulations.

Effectiveness is one of the key criteria for assessing business performance and expresses the extent to which the objectives are met and the conditions for their fulfilment in the future are created (Tumpach, 2008).

According to Lisý (2007) efficiency is the ability of the economy and economic entities to use existing resources as rationally as possible, to produce on the production possibility 
frontier and to use rare manufacturing factors.

From the natural point of view of production process, efficiency can be expressed as a relationship between natural resources, pointing out the productivity of different types of production factors, for example material, work and so on (Bielik 1996).

Heyne (1991) characterizes efficiency as a goodness, which is most appreciated among economists. He also understands it as a relation of something to something.

Company`s output are products and services generated from the consumption of inputs. The ratio of input to output expresses business efficiency (Synek 2000). Inputs include costs, material, labour, energy and so on. Outputs can be for example volume of the production, sales and revenues, value added and so on (Jenčová 2011).

Currently there are new approaches to monitoring business performance, which are based on a traditional system and supplement it with other aspects. Modern way of performance evaluation is based on the assumption that business achieves high performance if it is able to achieve predetermined strategic objectives. In practice, there are two basic approaches.

The first one is based on defining and evaluating strategic objectives for four basic areas (financial, customer, internal processes and learning and growth), so the Balanced Scorecard (BSC) (Kaplan, Norton 1992) is the balanced system of indicators. The second approach is based on performance measurement of organization through measuring the performance of processes (Performance Management). The common denominator of both approaches is their shift away from the assessment of business performance only on the basis of financial indicators and wide use of other types of indicators (qualitative and time indicators). This approach also uses efficiency indicators to evaluate performance.

In recent years, innovative approaches have started to apply in the area of business performance and efficiency measurement, for example matrix system of indicators addressed by linear programming model (Grell, Hyránek 2012) as well as non-standard method for efficiency measurement - DEA (Data Envelopment Analysis). DEA is non-parametric method which has many advantages compared to conventional methods for measurement of the efficiency. This method represents a specific area of linear programming application. It was originally developed to assess the efficiency of management and planning of non-profit institutions. In addition to efficiency calculation, its use later extended to other areas, for example to business performance and financial health assessment. With the use of DEA we can compare the efficiency and performance of a large number of businesses. DEA is addressed by Charnes, Cooper and Rhodes (1978) (DEA CCR), resp. Banker, Charnes and Cooper (1984) (DEA BCC). We can find the application of this method in works of Feruś (2010), Premachandra (2011) and others.

\section{Data and Methodology}

The research problem of the paper was focused on the analysis of business performance and efficiency. Business performance was calculated with the use of EVA indicator, efficiency 
was quantified by linear programming model aimed at addressing the problem of input and output transformations applying matrix model.

The formulation of research problem is as follows: The measurement of efficiency based on matrix model addressed by linear programming is a suitable alternative to performance measurement applying the EVA indicator.

The aim of the paper was to quantify and analyse business performance using the EVA indicator and to calculate and analyse business efficiency with the use of matrix model addressed as linear programming model by simplex method. The partial aim was to compare results of applied methods and answer the research question: Is effective business doing well in terms of performance?

Research sample consists of 30 Slovak companies doing a business in the field of heat supply. To solve the research problem and calculate performance of the analysed sample of businesses we used the data from the financial statements published in the Register of financial statements (RUZ 2016). Analysis of businesses shows that they have problems with liquidity and profitability. Their average indebtedness is at the level of $56 \%$, while the majority of it is current debt. Since all these businesses are local heat distribution systems, their market share and sales are more or less stable. Therefore it is very important to analyse the efficiency and performance of these businesses.

To quantify the performance of analysed businesses we used the EVA Equity model and its formula:

$$
E V A_{\text {Ranitv }}=\left(R O E-r_{e}\right) \times E
$$

where ROE is Return on Equity, $r_{\mathrm{e}}$ represents Cost of Equity and E stands for Equity and the EVA Entity model with the formula:

$$
E V A_{\text {Rntitv }}=\text { NOPAT }- \text { WACC } \times C,
$$

where NOPAT is Net Operating Profit after Tax, WACC stands for Weighted Average Cost of Capital and $\mathrm{C}$ represents Paid Capital.

Cost of Equity which enters into the above-mentioned formulas was calculated based on the INFA model according to formula:

$$
r_{r}=r_{f}+R P,
$$

where $\mathrm{r}_{\mathrm{f}}$ is Risk-free Rate of Return and RP stands for Risk Premium.

Risk Premium is calculated with the use of internal risks according to formula: 


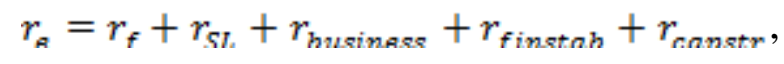

where $\mathrm{r}_{\mathrm{SL}}$ is Risk Premium for lower stocks liquidity in the market, $\mathrm{r}_{\text {business }}$ stands for Risk Premium for business risk, $r_{\text {finstab }}$ is Risk Premium for financial stability risk and $r_{\text {capstr }}$ represents Risk Premium for capital structure risk.

To create matrix model for the evaluation of efficiency and performance of businesses from the Slovak heat industry, we selected these inputs: $C-$ Costs, $M C-$ Material Costs, $A-$ Assets, FA - Fixed Assets, E - Equity and these outputs: EAT - Earnings after Taxes, EBITEarnings before Interest and Taxes, VA - Value Added, $R$-Revenues, $S$-Sales. With the use of mentioned inputs and outputs we created matrix of input and output transformations, which consists of average value of a number of important indicators of business performance (Table 1).

Table 1. Matrix model

\begin{tabular}{lcccccccccc}
\hline & EAT & EBIT & VA & R & S & C & MC & A & FA & E \\
\hline C & 0.04 & 0.06 & 0.25 & 1.05 & 1.05 & 1 & 0.58 & 1.46 & 1.13 & 0.65 \\
MC & 0.06 & 0.11 & 0.44 & 1.80 & 1.62 & 1.72 & 1 & 2.51 & 1.93 & 1.11 \\
A & 0.03 & 0.04 & 0.17 & 0.72 & 0.65 & 0.68 & 0.40 & 1 & 0.77 & 0.44 \\
FA & 0.03 & 0.06 & 0.23 & 0.93 & 0.84 & 0.89 & 0.52 & 1.30 & 1 & 0.57 \\
E & 0.06 & 0.10 & 0.39 & 1.62 & 1.46 & 1.55 & 0.90 & 2.26 & 1.75 & 1 \\
EAT & 1 & 1.72 & 6.88 & 28.37 & 25.58 & 27.06 & 15.77 & 39.53 & 30.50 & 17.48 \\
EBIT & 0.58 & 1 & 3.99 & 16.47 & 14.86 & 15.71 & 9.16 & 22.96 & 17.71 & 10.15 \\
VA & 0.15 & 0.25 & 1 & 4.12 & 3.72 & 3.93 & 2.29 & 5.75 & 4.43 & 2.54 \\
R & 0.04 & 0.06 & 0.24 & 1 & 0.90 & 0.95 & 0.56 & 1.39 & 1.08 & 0.62 \\
S & 0.04 & 0.07 & 0.27 & 1.11 & 1 & 1.55 & 0.62 & 1.55 & 1.19 & 0.68 \\
\hline
\end{tabular}

Explanatory notes:

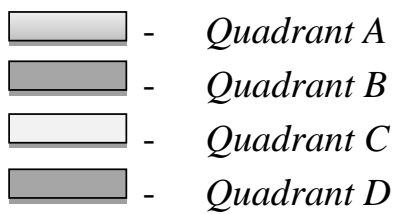

Source: Authors

Quadrant A in the matrix model consists of indicators of efficiency and effectiveness. Quadrant B is formed by indicators of assets structure and capital structure. Quadrant C consists of indicators constructed as input/output. This group includes indicators of intensity. Quadrant D is formed by indicators constructed as output/output. This group includes indicators of structure and also profitability indicators. From the construction of the matrix it is obvious, that it is created by indicators from all areas which determine performance. In the matrix there are indicators of efficiency, effectiveness and intensity and from the financial indicators there are indicators of profitability, activity and capital structure. 


\section{Macrothink

The calculation of efficiency based on matrix model was addressed as the optimization problem of linear programming in Microsoft Excel and its tool Investigator. The optimization task was to maximize the difference between the sum of indicators of efficiency and the sum of indicators of intensity. The aim of the linear programming was to find the optimum value of this difference in such a way that the values of all ratios are at the level of the optimal solution. When creating the model, it was necessary to pay attention to the accuracy of determining limiting conditions. The solution of this task was based on its simplification, in which the deviations between the indicators of intensity and efficiency were minimized. Vectors $\boldsymbol{u}_{\boldsymbol{i}}$ (linked to the indicators of intensity) and vectors $\boldsymbol{t}_{\boldsymbol{r}}$ (linked to the indicators of efficiency) were obtained as a solution to the equation (Grell, Hyránek 2012):

$$
\min \Sigma_{i} w_{i}=z
$$

s. t.

$$
\begin{gathered}
\sum_{i} u_{i} S_{M, i j}^{J}-\sum_{r} t_{r} c_{r j}-w_{j}=0 ; \\
\sum t_{r}=1 ; \\
u_{i}, t_{r}, w_{j}=0,
\end{gathered}
$$

where $w_{j}$ are the deviations between the indicators of intensity and efficiency by individual years, $j=$ $1,2,3, \ldots, 30, \mathrm{u}_{\mathrm{i}}$ stands for a vector of indicators of intensity, i represents the number of indicators of intensity, $t_{r}$ stands for a vector of indicators of efficiency, $r$ represents the number of indicators of efficiency, $\mathrm{S}_{\mathrm{M}, \mathrm{ij}}^{\mathrm{J}}$ is a matrix of indicators of intensity and $\mathrm{c}_{\mathrm{rj}}$ is a matrix of indicators of efficiency. The efficiency was calculated with the use of the formula:

$$
E_{j}=\sum_{r} t_{r} c_{r j} / \Sigma_{i} u_{i} S_{M i j}^{I}
$$

The matching score of businesses from Slovak heat industry according to achieved efficiency and performance was measured by Spearman`s rank correlation coefficient. This coefficient is used to determine whether two variables $(X, Y)$ are correlated or not. In this paper we examined the correlation between variables $X=K_{E}$ and $Y=K_{V}$. When calculating Spearman`s "p" of two independent variables $K_{E}=\left(K_{E 1}, K_{E 2}, \ldots K_{E n}\right)$ and $K_{V}=\left(K_{V 1}, K_{V 2}, \ldots K_{V n}\right)$ of the same range " $\mathrm{n}$ ", we firstly assigned a ranking to each business within the $R_{K E i}$, resp. $R_{K V i}$ set. Then we made a difference between rankings $d_{i}=R_{K E i}-R_{K V i}$ for all businesses within the research sample. If the same values are not 
repeated in the sets, it is not necessary to calculate average ranking and we can calculate Spearman`s coefficient by the formula:

$$
p=1-\frac{6 \times \sum_{i 1}^{n} d_{i}^{n}}{n \times\left(n^{2}-1\right)}
$$

Values of the coefficient closer to 0 indicate a weaker relationship between variables, values closer to 1 or -1 point to stronger relationship. Value 1 corresponds to total match of two rankings, value -1 means the inverse rankings.

\section{Results and Discussion}

To measure performance of analysed sample we calculated the average value of the indicators EVA Equity and EVA Entity. Figure 1 shows business performance ranking based on this average value. We can see that 14 businesses from the analysed sample achieved positive value of the EVA indicator and 16 businesses achieved the negative value of this indicator. Therefore we can say that these businesses have problems with their performance. More detailed analysis showed that these problems are caused by low liquidity and profitability of the analysed sample of businesses.

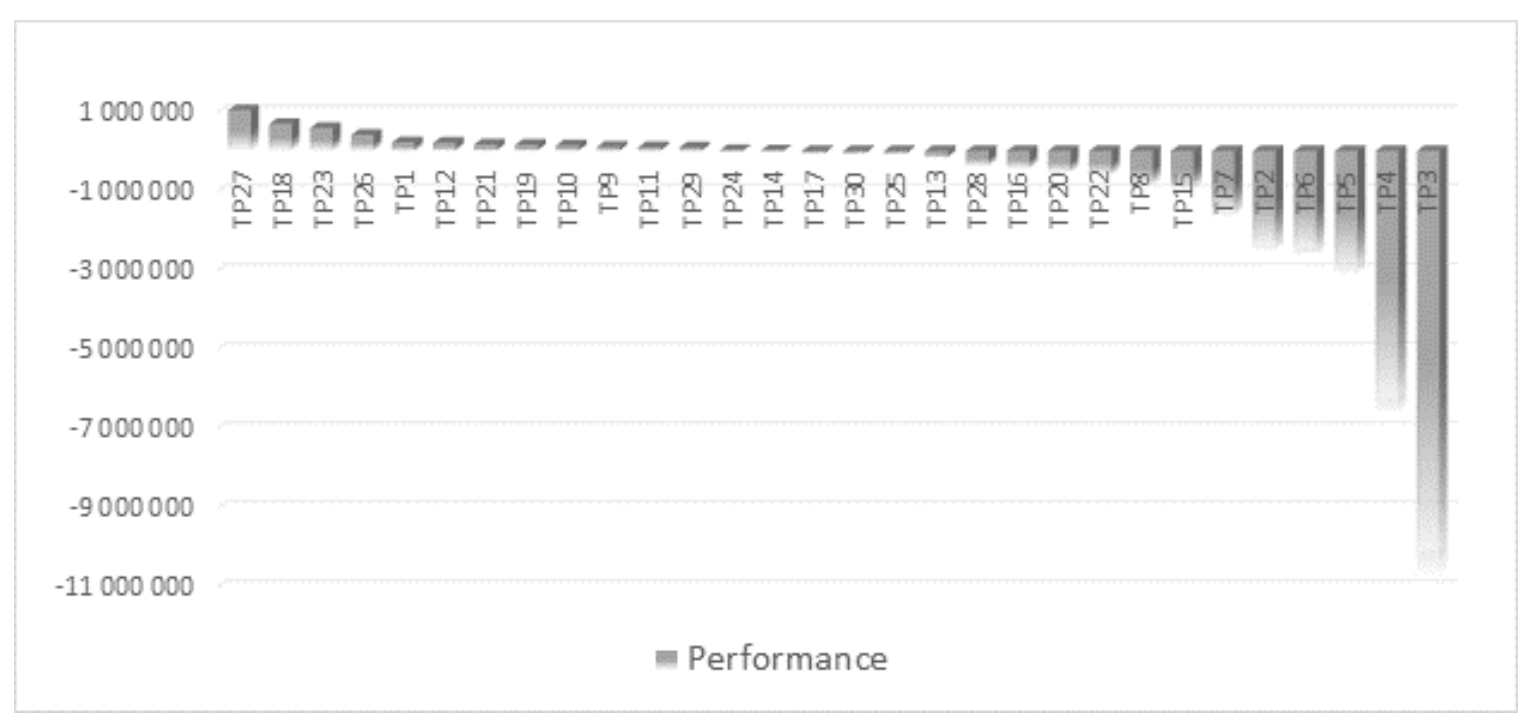

Figure 1. Businesses’ Performance Ranking (€)

Source: Authors

We also examined the differences between the values of EVA Equity, EVA Entity and average EVA. We found out that these differences were minimal (see Figure 2). It means that businesses do not have high paid debt within their capital structure. This is confirmed by high values of Interest coverage, the average value of this indicator was at the level of 1340. 


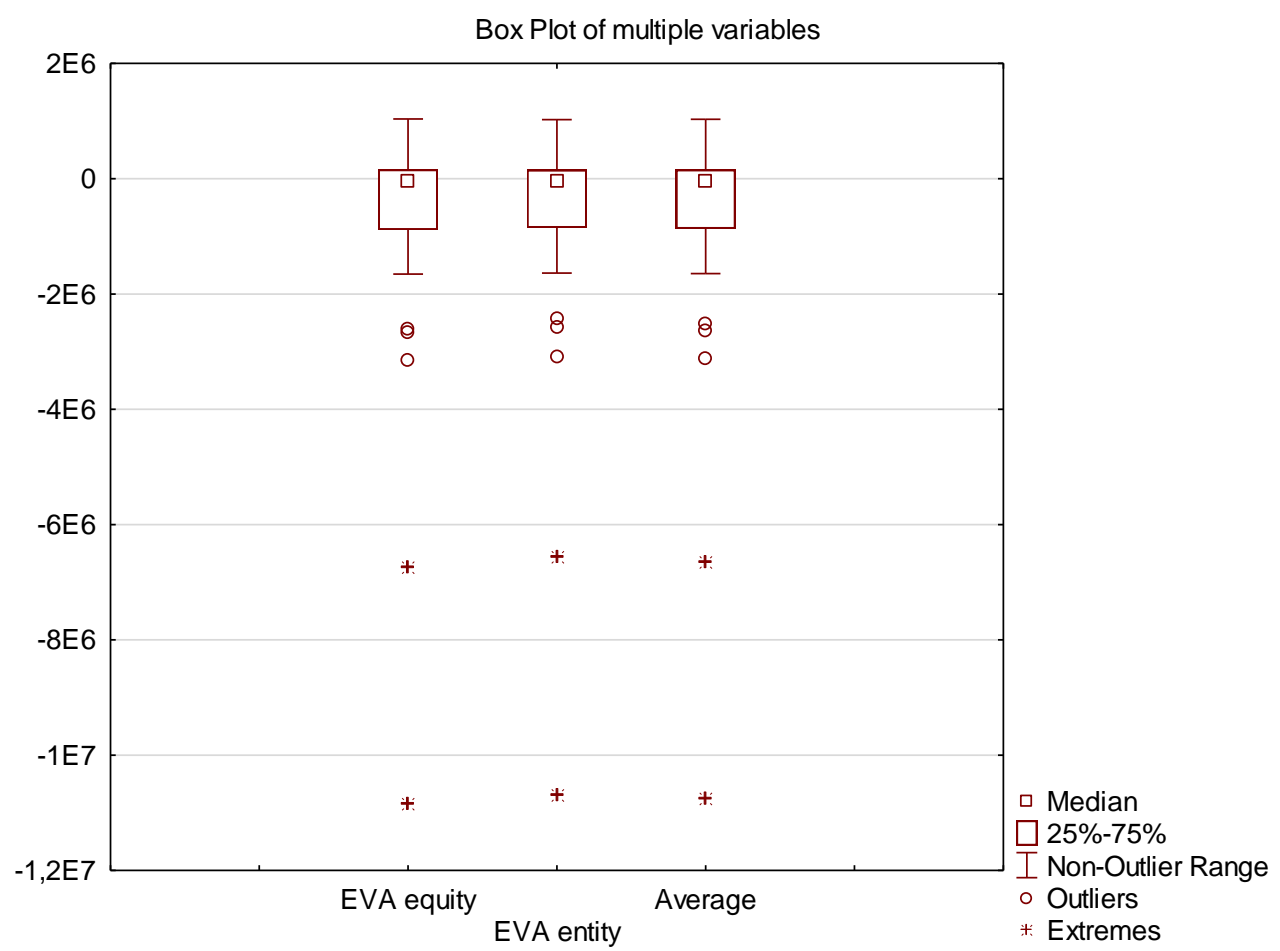

Figure 2. Comparison of EVA Equity, EVA Entity and Average EVA

Source: Authors

To measure the efficiency of the analysed sample, we formulated the problem of linear programming (Table 2). We selected these indicators of intensity: $\mathrm{x}_{1}-$ Cost ratio, $\mathrm{x}_{2}-$ Assets intensity, $\mathrm{x}_{3}-$ Capital intensity, $\mathrm{x}_{4}$ - Material intensity and these indicators of effectiveness: $\mathrm{x}_{5}$ - Return on sales, $\mathrm{x}_{6}-$ Return on equity, $\mathrm{x}_{7}-$ Return on assets, $\mathrm{x}_{8}-$ Fixed assets turnover.

Table 2. Solving of the Problem of Linear Programming

\begin{tabular}{|c|c|c|c|c|c|c|c|c|c|c|c|c|}
\hline & $\mathbf{u} 1$ & $\mathbf{u} 2$ & $\mathbf{u 3}$ & $\mathbf{u} 4$ & $\mathbf{t}_{1}$ & $\mathbf{t}_{2}$ & $\mathbf{t}_{3}$ & $\mathbf{t}_{4}$ & W1 & W2 & $\ldots .$. & \\
\hline & $\mathbf{X}_{1}$ & $\mathbf{X}_{2}$ & $\mathbf{X 3}$ & $\mathbf{X} 4$ & $\mathbf{X 5}$ & X6 & $\mathbf{X}_{7}$ & X8 & X9 & $\mathbf{X} 10$ & $\ldots .$. & \\
\hline & 1 & 2 & 3 & 4 & 5 & 6 & 7 & 8 & 9 & 10 & $\ldots$. & \\
\hline 1 & 0.975 & 0.484 & 0.219 & 0.696 & 0.039 & 0.107 & 0.104 & 2.067 & -1 & & & $=0$ \\
\hline 2 & 0.997 & 0.912 & 0.445 & 0.259 & -0.002 & -0.002 & 0.011 & 1.097 & & -1 & & $=0$ \\
\hline 3 & 0.998 & 1.863 & 1.436 & 0.549 & 0.000 & 0.000 & 0.013 & 0.537 & & & $\ldots$. & $=0$ \\
\hline 4 & 0.990 & 2.197 & 1.957 & 0.550 & 0.003 & 0.002 & 0.014 & 0.455 & & & & $=0$ \\
\hline 5 & 0.928 & 1.820 & 1.569 & 0.435 & 0.057 & 0.053 & 0.041 & 0.549 & & & & $=0$ \\
\hline$\vdots$ & $\vdots$ & $\vdots$ & $\vdots$ & $\vdots$ & $\vdots$ & $\vdots$ & $\vdots$ & $\vdots$ & & & & $\vdots$ \\
\hline 29 & 0.931 & 0.982 & 0.795 & 0.649 & 0.055 & 0.344 & 0.081 & 1.018 & & & & $=0$ \\
\hline \multirow[t]{4}{*}{30} & 0.965 & 2.173 & 2.007 & 0.540 & 0.030 & 0.076 & 0.023 & 0.460 & & & & $=0$ \\
\hline & & & & & 1 & 1 & 1 & 1 & & & & $=1$ \\
\hline & $\mathrm{u}_{1}$ & $\mathrm{u}_{2}$ & $\mathrm{u}_{3}$ & $\mathrm{u}_{4}$ & $\mathrm{t}_{1}$ & $\mathrm{t}_{2}$ & $\mathrm{t}_{3}$ & $\mathrm{t}_{4}$ & $\mathrm{w}_{1}$ & $\mathrm{w}_{2}$ & $\ldots$. & $\geq 0$ \\
\hline & & & & & & & & Min & $\mathrm{w}_{1}+$ & $\mathrm{w}_{2}+$ & $\ldots$. & $=\mathrm{Z}$ \\
\hline
\end{tabular}

Explanatory notes:

$w_{j}$ - deviations

Source: Authors 
Table 3 shows the result of the problem of linear programming. Vectors $u_{i}$ and $t_{r}$ represent weights of selected indicators. We can see that the highest weight in the model have indicators Return on sales, Cost ratio, and Fixed assets turnover. Therefore we can consider these indicators as the most important determinants of business efficiency. In the model we minimized deviations $w_{i}$ while the average $w_{i}$ was 0.17 .

Table 3. Results of the Problem of Linear Programming

\begin{tabular}{lll}
\hline & Vector $u_{i}$ & Vector $t_{r}$ \\
\hline$u_{1}=0.291$ & $t_{1}=0.954$ \\
$u_{2}=0$ & $t_{2}=0$ \\
$u_{2}=0$ & $t_{a}=0$ \\
$u_{4}=0$ & $t_{4}=0.046$
\end{tabular}

Source: Authors

With the use of above-mentioned weights and the formula provided in the section Data and methodology, we can calculate the efficiency of businesses from analysed sample and create efficiency ranking (Figure 3).

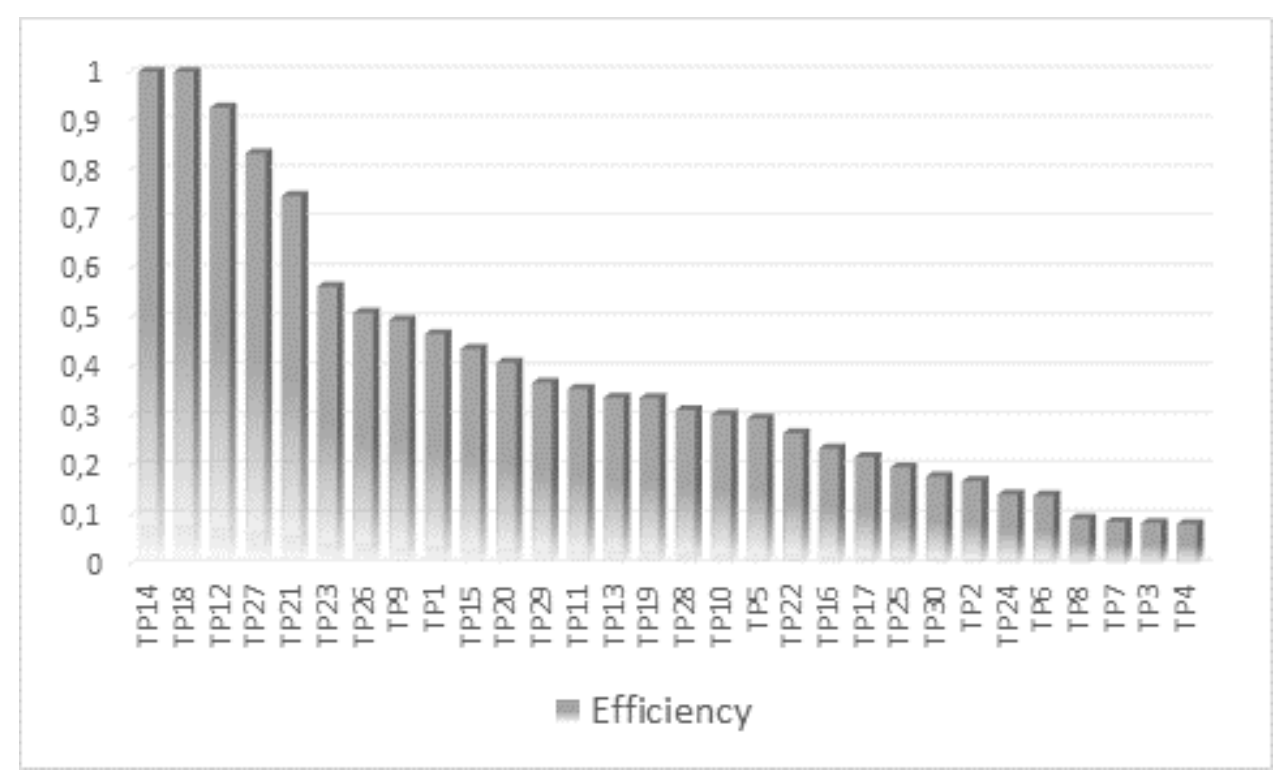

Figure 3. Businesses`Efficiency Ranking

Source: Authors

Based on the results of efficiency calculation we can say that only 2 businesses from the analysed sample achieved maximum value of efficiency at the level of 1 . On the other hand 4 
businesses from the analysed sample achieved lower efficiency than 0.1 .

More detailed analysis and comparison of efficiency with performance is shown in Table 4. Based on the results listed in this table we can conclude that low-efficiency businesses also reach the negative value of the EVA indicator, so their performance is low. We also found out that businesses, which efficiency is less than 0.3, achieve low performance and businesses, which efficiency is more than 0.5 and less than 1 , achieve high performance. In the efficiency range from 0.3 to 0.5 there is a grey area where we cannot definitely say whether businesses are doing well in terms of performance or not. In this range businesses achieved positive and also negative value of the EVA indicator. Business TP27 which reached the highest value of the EVA indicator at the level of $1030459.04 €$, achieved the efficiency of 0.83 . We can also mention business TP18, which reached the second place in the value of the EVA indicator and also in the efficiency calculation.

Table 4. Comparison of Businesses` Ranking in terms of EVA Indicator and Efficiency

\begin{tabular}{rrrrrr}
\hline $\begin{array}{c}\text { Businesses } \\
\text { ranking }\end{array}$ & EVA & Efficiency & $\begin{array}{r}\text { Businesses } \\
\text { ranking }\end{array}$ & EVA & Efficiency \\
\hline 1 & TP27 & TP14 & 16 & TP30 & TP28 \\
2 & TP18 & TP18 & 17 & TP25 & TP10 \\
3 & TP23 & TP12 & 18 & TP13 & TP5 \\
4 & TP26 & TP27 & 19 & TP28 & TP22 \\
5 & TP1 & TP21 & 20 & TP16 & TP16 \\
6 & TP12 & TP23 & 21 & TP20 & TP17 \\
7 & TP21 & TP26 & 22 & TP22 & TP25 \\
8 & TP19 & TP9 & 23 & TP8 & TP30 \\
9 & TP10 & TP1 & 24 & TP15 & TP2 \\
10 & TP9 & TP15 & 25 & TP7 & TP24 \\
11 & TP11 & TP20 & 26 & TP2 & TP6 \\
12 & TP29 & TP29 & 27 & TP6 & TP8 \\
13 & TP24 & TP11 & 28 & TP5 & TP7 \\
14 & TP14 & TP13 & 29 & TP4 & TP3 \\
15 & TP17 & TP19 & 30 & TP3 & TP4 \\
\hline
\end{tabular}

Source: Authors

When calculating the matching order, we applied Spearman`s rank correlation. Ranking of businesses according to their performance and efficiency is shown in table 5. The order of businesses TP16, TP18 and TP29 in terms of performance and efficiency is the same. For these businesses we can definitely say that efficient business is also doing well in terms of performance. Four businesses reached the lowest difference in order at the level of 1 . The highest difference in order at the level of 196 reached business TP18. The difference in order at the level of 3 occurred in the case of 7 businesses. 


\section{$\Lambda$ Macrothink}

The result of Spearman`s rank correlation coefficient is 0.76 . This value points to stronger relationship between performance and efficiency, but it is not a total match of rankings.

Table 5. Difference in Order

\begin{tabular}{lrrrlrrr}
\hline Business & $\begin{array}{c}\text { Performance } \\
\text { ranking }\end{array}$ & $\begin{array}{c}\text { Efficiency } \\
\text { ranking }\end{array}$ & di $^{2}$ & Business & Performance & Efficiency \\
ranking & ranking & di $^{2}$ \\
\hline TP1 & 5 & 9 & 16 & TP16 & 20 & 20 & 0 \\
TP2 & 26 & 24 & 4 & TP17 & 15 & 21 & 36 \\
TP3 & 30 & 29 & 1 & TP18 & 2 & 2 & 0 \\
TP4 & 29 & 30 & 1 & TP19 & 8 & 15 & 49 \\
TP5 & 27 & 18 & 81 & TP20 & 21 & 11 & 100 \\
TP6 & 27 & 26 & 1 & TP21 & 7 & 5 & 4 \\
TP7 & 25 & 28 & 9 & TP22 & 22 & 19 & 9 \\
TP8 & 23 & 27 & 16 & TP23 & 3 & 6 & 9 \\
TP9 & 10 & 8 & 4 & TP24 & 13 & 25 & 144 \\
TP10 & 9 & 17 & 64 & TP25 & 17 & 22 & 25 \\
TP11 & 11 & 13 & 4 & TP26 & 4 & 7 & 9 \\
TP12 & 6 & 3 & 9 & TP27 & 1 & 4 & 9 \\
TP13 & 18 & 14 & 16 & TP28 & 19 & 16 & 9 \\
TP14 & 14 & 1 & 169 & TP29 & 12 & 12 & 0 \\
TP15 & 24 & 10 & 196 & TP30 & 16 & 23 & 49 \\
\hline S0urce & & & & & & &
\end{tabular}

Source: Authors

\section{Conclusion}

Performance should be examined from the several points of view. The application of matrix system of indicators, which includes both inputs and outputs, is an appropriate unconventional and innovative approach to measuring business performance. Addressing the problem of performance measurement applying linear programming model provides new areas of knowledge. This primary model can be further developed to examine various inputs and outputs and their impact on business performance. Conventional inputs of matrix system of indicators can be replaced by financial ratios. With the use of them we can study and predict business financial health.

Based on the research we can say that efficiency is important prerequisite for business performance, i.e. business performance can be measured by efficiency. We can claim it based on the fact that performance represents one aggregate value which includes several areas of business financial health and performance. We can prove that performance of efficient business is high. This was confirmed by many transformations of models which were initially focused on efficiency measurement. Nowadays, these models are used to measure performance and financial health of businesses. The EVA indicator which we quantified in this paper provided us with about the same results as the model of input and output 
transformations, of course, except for some specific deviations. The value of Spearman`s rank correlation coefficient indicates that measurement of efficiency based on matrix model addressed by linear programming is a suitable alternative to performance measurement applying the EVA indicator.

Out next research will be focused on more precise selection of inputs and outputs as well as the selection of research sample. Our goal is to make more accurate classification of businesses according to performance portfolio. The aim of our research is to formulate a dual model with the application of new inputs and outputs.

\section{Acknowledgement}

This paper was prepared within the grant scheme VEGA no. 1/0887/17 - Increasing the competitiveness of Slovakia within the EU by improving efficiency and performance of production systems.

\section{References}

Banker, R. D., Charnes, A., \& Cooper, W.W. (1984). Some Models for Estimating Technical Scale Inefficiencies in Data Envelopment Analysis. Management Science, 30(9), 1078-1092. https://doi.org/10.1287/mnsc.30.9.1078

Bielik, P. et al. (1999). Ekonomika pol’nohospodárstva a európska integrácia. Nitra: SPU.

Charnes, A., Cooper, W.W., \& Rhodes, E. (1978). Measuring the Efficiency of Decision Making Units. European Journal of Operational Research, 2(6), 429-444. https://doi.org/10.1016/0377-2217(78)90138-8

Doyle, P. (1998). Marketing Management and Strategy. (2nd ed.). London: Prentice Hall Europe. https://doi.org/10.1108/03090569810216145

Feruś, A. (2010). The Application of DEA Method in Evaluating Credit Risk of Companies. Contemporary Economics, 4(4). https://doi.org/10.15388/Ekon.2009.0.5126

Fibírová, J., \& Šoljaková, L. (2005). Hodnotové nástroje řizeni a měrení výkonnosti podniku. (1th ed.). Praha: ASPI, a.s.

Frost, W. (2005). ABC`s of Activity Based Management - Crushing competition through performance improvement. Bloomington: iUniverse LLC.

Grell. M., \& Hyránek, E. (2012). Maticové modely na meranie výkonnosti produkčných systémov. Ekonomika a management. 1, 73-88.

Heyne, P. (1991). Ekonomický styl myšlení. Praha: VŠE.

Jenčová, S. (2011). Finančno-ekonomická analýza podnikatel’kých subjektov. Prešov: Grafotlač, s.r.o. 
Johnson, G., \& Kevan, S. (2000). Cesty k úspešnému podnikaniu. Praha: Computer Press.

Kaplan, R. S., \& Norton, D. P. (1992). The Balanced Scorecard: Measures that Drive Performance. Harvard Business Review, 70(1), 71-79.

Lisý, J. et al. (2007). Ekonómia v novej ekonomike. (2nd ed.). Bratislava: Iura Edition, spol. s.r.o.

Nenadál, J. (2004). Měrení v systémech managementu jakosti. Praha: Management Press.

Neumaierová, I., \& Neumaier, I. (2002). Výkonnost a tržni hodnota firmy. Praha: Grada Publishing.

Neumaierová, I. (2003). Aplikace řízeni hodnoty. Praha: Vysoká škola ekonomická v Praze. Nakladatelství Oeconomica.

Premachandra, I. M., Chen, Y., \& Watson, J. (2011). DEA as a Tool for Predicting Corporate Failure and Success: A Case of Bankruptcy Assessment. Omega, 39(6), 620-626. https://doi.org/10.1016/j.omega

Rolstadas, A. (2014). Enterprise performance measurement. Business and Economics -Management. Bradford: Emerald Group Publishing, 18 (9/10). Retrieved from http://search.proquest.com/docview/232335479?accountid=49283 (December 22, 2017).

RÚZ (2016). Register účtovných závierok. Retrieved from http://www.registeruz.sk/cruz-public/home/ (December 15, 2016).

Sedláček, M., Suchánek, P., \& Špalek, J. (2012). Kvalita a výkonnost průmyslových podniků. Brno: Masarykova univerzita. https://doi.org/10.5817/CZ.MUNI.M210-6075-2012

Sink, D. S., \& Tuttle, T. C. (1989). Planning and Measurement in Your Organisation of the Future. Ch. 5. Industrial Engineering and Management Press. Norcross. GA. pp. 170-184

Smith, T. M., \& Reece, J. S. (1999). The relationship of strategy, fit, productivity, and business performance in a services setting. Journal of Operations Management, 17(2), 145-161. https://doi.org/10.1016/S0272-6963(98)00037-0

Souček, Z. (2010). Firma 21. Století: (Předstihněme nejlepši!!!). Praha: Professional Publishing.

Stýblo, J. (2008). Výkonnost’ firiem. Moderní ř́zení. 43(11), 25. Retrieved August 25, 2017 from https://modernirizeni.ihned.cz/c1-30557910-vykonnost-firem

Suchánek, P. et al. (2013). Vliv kvality na výkonnost a konkurenceschopnost podniku. (1th ed.). Brno: Masarykova univerzita. https://doi.org/10.5817/CZ.MUNI.M210-6627-2013

Synek, M. et al. (2000). Manažérska ekonomika. Praha: Grada Publishing, a.s.

Šulák, M., \& Vacík, E. (2005). Měření výkonnosti firem. Plzeň: Západočeská univerzita.

Tumpach, M. (2008). Manažérske a nákladové účtovníctvo. Bratislava: Iura Edition. 


\section{Macrothink}

Valach, J. (1998). Finanční řízení podniku. (2nd ed.). Praha: Ekopress.

Wagner, J. (2009) Měrení výkonnosti. (1th ed.). Praha: GRADA Publishing. p. 17.

\section{Copyright Disclaimer}

Copyright for this article is retained by the author(s), with first publication rights granted to the journal.

This is an open-access article distributed under the terms and conditions of the Creative Commons Attribution license (http://creativecommons.org/licenses/by/3.0/). 